\title{
HUBUNGAN KEPATUHAN KONSUMSI TABLET FE DENGAN KEJADIAN ANEMIA PADA IBU POST PARTUM DI WILAYAH KERJA PUSKESMAS PAYUNG SEKAKI PEKANBARU
}

\author{
Islah Wahyuni \\ Program Studi Diploma III Kebidanan STIKes Payung Negeri Pekanbaru Riau \\ Korespodensi penulis: islah_fattan@yahoo.co.id
}

\begin{abstract}
Abstrak
Latar belakang dan tujuan: Kepatuhan mengkonsumsi tablet Fe merupakan perilaku positif yang dilakukan oleh klien yang mengarah ketujuan teraupetik yang telah di sepakati bersama. Kepatuhan ibu hamil dalam mengkonsumsi tablet Fe berhubungan positif dengan kejadian anemia. Manfaat kepatuhan bagi ibu dan bayi yaitu mencegah terjadinya komplikasi kehamilan dan persalinan seperti persalinan premature, partus lama, inersia uteri, atonia uteri dan lain-lain. Penelitian ini bertujuan untuk mengidentifikasi hubungan kepatuhan konsumsi tablet Fe pada ibu dengan pelaksanaan kejadian anemia pada ibu postp artum.

Metode: Penelitian ini menggunakan jenis penelitian Quasi eksperimen dengan pendekatan prospektif. Penelitian ini dilaksanakan di Wilayah Kerja Puskesmas Payung Sekaki Pekanbaru pada Januari-April 2019 dengan jumlah sampel yang di teliti adalah 20 responden. Teknik pengambilan sampel yang digunakan pada penelitian ini adalah Consencutive Sampling. Instrumen penelitian adalah kuesioner dan kadar HB menggunakan $\mathrm{Hb}$ test meter. Analisis data menggunakan Rank Spearman.

Hasil: Hasil penelitian menunjukkan kepatuhan responden dalam mengkonsumsi tablet Fe baik (65\%). diperoleh kejadian anemia pada 10 responden $(50 \%)$ pasca persalinan, dan rata-rata kadar Haemoglobin responden pasca bersalin adalah $10.850 \mathrm{gr} \%$.

Simpulan: Terdapat hubungan variable kepatuhan ibu dalam mengkonsumsi tablet Fe dengan kejadian anemia $p$ value $(0,010)$. Dari hasil penelitian diharapkan kepada tenaga kesehatan untuk dapat meningkatkan penyuluhan dan edukasi untuk menambah pemahaman ibu tentang pentingnya mengkonsumsi tablet Fe selama kehamilan.
\end{abstract}

Kata kunci: ibu post partum, kejadian anemia, kepatuhan, tablet Fe.

\section{Pendahuluan}

Survey Demografi Kesehatan Indonesia (SDKI) tahun 2012, Angka Kematian Ibu (AKI) masih cukup tinggi yaitu 359/100.000 kelahiran hidup. Penyebab kematian ibu paling banyak terjadi pada masa nifas, yaitu karena pendarahan setelah persalinan $28 \%$, eklamsia $24 \%$, infeksi $11 \%$, kurang energi setelah melahirkan 9\%, abortus 5\%, partus lama $5 \%$, emboli $3 \%$ dan anemia $3 \%$ (Suwandi, 2010).

Menurut World Health Organization (WHO, 2012) anemia merupakan salah satu masalah kesehatan di seluruh dunia terutama negara berkembang yang diperkirakan 30\% penduduk dunia menderita anemia. Anemia banyak terjadi pada masyarakat terutama pada ibu hamil dan nifas. Berdasarkan data hasil Riskesdas (2013), prevalensi anemia di Indonesia yaitu terdapat $13,32 \%$ ibu hamil dengan anemia dan 50,5\% dengan penderita anemia pada ibu nifas.

Anemia pada masa nifas dapat terjadi pada ibu, dimana setelah melahirkan kadar hemoglobin kurang dari normal, dan kondisi ini dapat menyebabkan kehilangan zat besi dan dapat berpengaruh dalam proses laktasi dan dapat mengakibatkan rahim tidak berkontraksi karena darah tidak cukupmemberikan oksigen ke rahim (Azwar, 2009). Anemia post partum diartikan apabila 
kadar $\mathrm{Hb}<12$ g / dL pada minggu ke 1 minggu pascapersalinan dan $<12 \mathrm{~g} / \mathrm{dL}$ pada minggu ke 8 minggu pascapartum. Penyebab utama anemia pascapartum adalah anemia pre-partum yang dikombinasikan dengan anemia perdarahan akut karena kehilangan darah saat melahirkan. Kehilangan darah peripartum normal kira-kira $300 \mathrm{ml}$, tapi perdarahan $>500 \mathrm{ml}$ terjadi pada 5-6\% wanita (Nils Milman, 2011).

Akibat dari anemia biasanya terjadi perdarahan, retensio plasenta, atonia uteri, dan bisa disebabkan pada masa hamilnya kurang mengkonsumsi tablet $\mathrm{Fe}$, dan bisa juga disebabkan oleh infeksi yang dapat mempengaruhi ibu nifas dalam melakukan aktivitas sehari-hari dan aktivitas menyusui dikarenakan penderita merasa mules, pusing dan cepat lelah (Wahyuni, 2015).

Penelitian (Nurul \& Dian, 2015) tentang Gambaran Hemoragic Post Partum (HPP) Pada Ibu Bersalin Dengan Kejadian Anemia Di Ruang Ponek RSUD Kabupaten Jombang, Hasil penelitian didapatkan ibu bersalin yang mengalami HPP sebanyak 23 responden $(55 \%)$ dan yang mengalami HPP dengan anemia sebanyak 21 responden $(50 \%)$, yg tdk anemia sebanyak 2 responden $(9,5)$ Kesimpulan dari penelitian ini adalah ibu bersalin yang mengalami HPP sebagian besar 23 responden dan yang mengalami HPP dengan anemia sebagian besar 21 responden disebabkan karena sebagian besar responden adalah multipara dan dari hasil penelitian ada hubungan antara HPP pada ibu bersalin dengan kejadian anemia.

Elizabeth, et.al. (2003) dalam penelitiannya tentang Low Hemoglobin Level Is a Risk Factor for Postpartum Depressionbahwa ibu yang mempunyai kadar HB yang rendah akan mempunyai resiko depresi postpartum. Hasil Skor CES-D (Studies-Depressive Symptomatology Scale) (mean \pm sem) pada hari ke-7 wanita dengan kadar $\mathrm{Hb}$ normal > (12 g / dL) secara signifikan lebih rendahdibandingkan dengan wanita dengan kadar $\mathrm{Hb} \leq 12 \mathrm{~g} / \mathrm{dL}$ ). Dengan demikian, wanita yang menderita anemia postpartum dini mungkin berisiko tinggi terkena PostPartum Depression (PPD) (Elizabeth, et.al. 2003). Kekurangan zat besi, penyebab umum anemia, mengubah metabolisme hormon tiroid. Semua gejala ini (kelelahan, anemia, status tiroid abnormal) mungkin saling terkait pada individu tertentu. Jika terjadi selama masa postpartum, mereka dapat mempengaruhi hasil kesehatan ibu(Ludwig, H. \& Strasser, K. 2001).

Cara yang paling andal untuk menangani masalah ini adalah memberi suplemen zat besi oral profilaksis $30-50 \mathrm{mg}$ setiap hari dari awal kehamilan dan melakukan tindakan pencegahan kebidanan pada kehamilan yang berisiko mengalami komplikasi. Dalam pengobatan anemia ringan pasca melahirkan yang menjadi pilihan pertama harus zat besi besi oral 100 sampai $200 \mathrm{mg}$ setiap hari; penting untuk menganalisis hemoglobin setelah kira-kira 2 minggu untuk memeriksa apakah pengobatan berhasil (Nils Milman, 2012).

Saat ANC, peran dari bidan sangat penting guna untuk meningkatkan deteksi dini dalam melakukan segala pemeriksaan khususnya pada pemeriksaan haemoglobin pada ibu nifas (Nurul \& Dian, 2015)

\section{Metode Penelitian}

Penelitian ini merupakan Quasi Experiment dilakukan pada ibu hamil trimester III ( 232 minggu) yang diberikan tablet Fe sebanyak 30 tablet, dan pemeriksaan kadar Haemoglobin pada ibu 2 jam pasca bersalin yang berada di wilayah kerja puskesmas payung sekaki kota Pekanbaru pada Januari-April 2019. Jumlah sampel 20 orang dipilih secara Consencutive sampling. Setiap variabel diukur menggunakan kuesioner dan kadar HB menggunakan $\mathrm{Hb}$ test meter. Data dianalisis dengan uji korelasi rank spearman

\section{Hasil dan pembahasan}

Hubungan Kepatuhan Konsumsi Tablet Fe Dengan Kadar haemoglobin Pada Ibu Post Partum Di Wilayah Kerja Puskesmas Payung Sekaki dapat dilihat pada tabel di bawah ini: 
Tabel 1. Karakteristik responden

\begin{tabular}{cccc}
\hline No & Umur & Frekuensi (f) & Persentase(\%) \\
\hline 1. & $17-25$ & 8 & 40 \\
2. & $26-35$ & 9 & 45 \\
3. & $36-45$ & 3 & 15 \\
\hline No & Pendidikan & & \\
\hline 1. & Pendidikan Dasar & 3 & 13 \\
2. & Pendidikan Menengah & 15 & 75 \\
3. & Perguruan Tinggi & 2 & 12 \\
\hline No & Paritas & & 20 \\
\hline 1. & Primi para & 4 & 80 \\
2. & Multi para & 16 & 40 \\
\hline No & Pekerjaan & 8 & 60 \\
\hline 1. & Bekerja & 12 & \\
2. & Tidak Bekerja & & \\
\hline
\end{tabular}

Tabel 2. Kepatuhan responden mengkonsumsi tablet Fe

\begin{tabular}{clcc}
\hline No & Kategori & Frekuensi(f) & Persentase $(\%)$ \\
\hline 1. & Patuh & 13 & 65 \\
2. & Tidak Patuh & 7 & 35 \\
\hline \multicolumn{2}{r}{ Jumlah } & $\mathbf{2 0}$ & $\mathbf{1 0 0}$ \\
\hline
\end{tabular}

Tabel 3. Tindakan pemasangan infuse responden saat persalinan

\begin{tabular}{ccccc}
\hline No & Kategori & Frekuensi(f) & Persentase $(\boldsymbol{\%})$ \\
\hline 1. & Ya & 7 & 35 \\
2. & Tidak & 13 & 65 \\
\hline \multicolumn{2}{c}{ Jumlah } & $\mathbf{2 0}$ & $\mathbf{1 0 0}$ \\
\hline
\end{tabular}

Tabel 4. Indikasi pemasangan infuse responden saat persalinan

\begin{tabular}{cccc}
\hline No & Kategori & Frekuensi(f) & Persentase(\%) \\
\hline 1. & Lelah & 3 & 42,8 \\
\hline 2 & His non adekuat & 4 & 57,2 \\
\hline \multicolumn{2}{c}{ Jumlah } & $\mathbf{7}$ & $\mathbf{1 0 0}$ \\
\hline
\end{tabular}

Tabel 5. Kategori anemia responden

\begin{tabular}{|c|c|c|c|}
\hline No & Kategori & Frekuensi (f) & Persentase $(\%)$ \\
\hline \multirow[t]{3}{*}{1.} & Anemia & 10 & 50 \\
\hline & Ringan & (7) & \\
\hline & - $\quad$ Sedang & (3) & \\
\hline \multirow[t]{2}{*}{2.} & Tidak Anemia & 10 & 50 \\
\hline & Jumlah & 20 & 100 \\
\hline
\end{tabular}




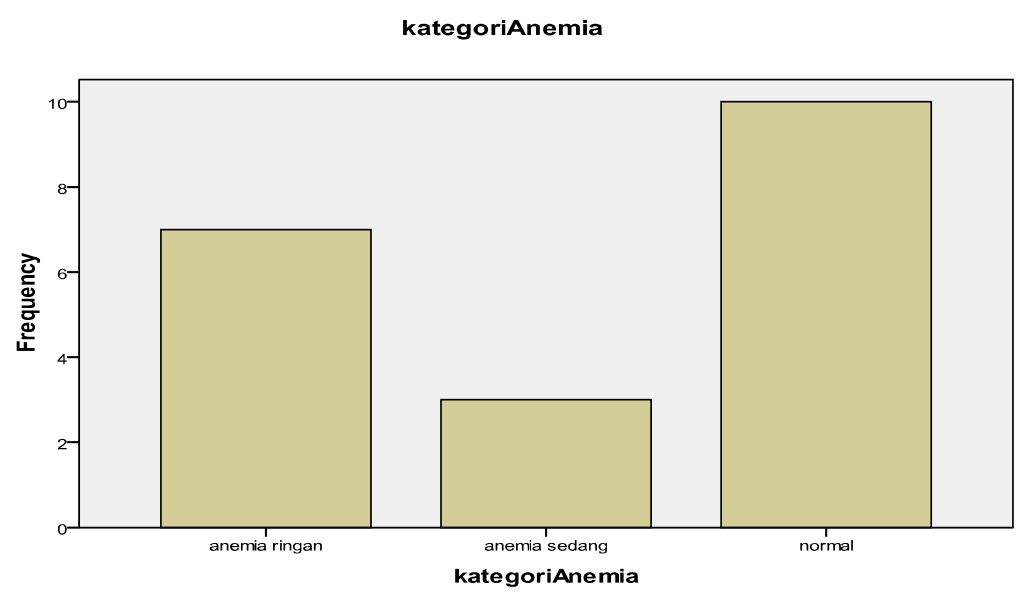

Tabel 6. Rata-rata Kadar HB Responden

\begin{tabular}{ccccc}
\hline Variable & $\begin{array}{c}\text { Mean } \\
(\mathbf{g r} / \mathbf{d L})\end{array}$ & $\begin{array}{c}\text { Median } \\
(\mathbf{g r} / \mathbf{d L})\end{array}$ & $\begin{array}{c}\text { SD } \\
(\mathbf{g r} / \mathbf{d L})\end{array}$ & $\begin{array}{c}\text { Min-Max } \\
(\mathbf{g r} / \mathbf{d L})\end{array}$ \\
\hline Nilai Haemoglobin postpartum & 10.850 & 11.250 & 1.8452 & $7.0-13.6$ \\
\hline
\end{tabular}

Tabel 7. Hubungan kepatuhan ibu mengkonsumsi tablet Fe dengan kejadian anemia

\begin{tabular}{|c|c|c|c|c|c|c|c|}
\hline \multirow[t]{3}{*}{ No } & \multirow[t]{3}{*}{ Kepatuhan } & \multicolumn{4}{|c|}{ Kejadian anemia } & \multirow[t]{2}{*}{ Jumlah } & \multirow[t]{2}{*}{$P$ value } \\
\hline & & Anemia & & $\begin{array}{c}\text { Tidak } \\
\text { anemia }\end{array}$ & & & \\
\hline & & $\mathbf{F}$ & $\%$ & $\mathbf{F}$ & $\%$ & & \\
\hline 1. & Patuh & 4 & 40 & 9 & 90 & 13 & 0,010 \\
\hline 2. & Tidak patuh & 6 & 60 & 1 & 10 & 7 & \\
\hline & Jumlah & 10 & 100 & 10 & 100 & 20 & \\
\hline
\end{tabular}

Pada aspek kepatuhan konsumsi tablet $\mathrm{Fe}$, diperoleh data mayoritas responden patuh dalam mengkonsumsi tablet $\mathrm{Fe}$ yaitu 13 responden, dan terdapat hubungan antara kepatuhan dalam mengkonsumsi tablet $\mathrm{Fe}$ dengan kejadian anemia $(p=0,010)$. Ini menggambarkan bahwa tingkat kepatuhan responden berbanding lurus dengan kadar haemoglobin (Anemia post partum) dengan rata-rata kadar $\mathrm{Hb}$ responden yaitu 10.850 $\mathrm{gr} / \mathrm{dL}$.

Kepatuhan merupakan perilaku positif yang dilakukan oleh klien yang mengarah ketujuan teraupetik yang telah di sepakati bersama. Jadi kepatuhan adalah suatu perilaku yang di lakukan oleh klien untuk menaati ketentuan atau kebijakan yang sudah ditetapkan (Rukmaini, et.al, 2018). Kepatuhan kunjungan antenatal care (ANC) merupakan ketaatan dalam melakukan kunjungan kepelayanan kesehatan oleh ibu hamil sesuai dengan saran dari petugas kesehatan dengan standar yang sudah di tetapkan yaitu minimal 4 kali dalam masa kehamilan (Hardiani \& Purwanti, 2012).

Suplementasi Fe rutin dalam kehamilan adalah praktik umum untuk mencegah defisiensi besi dan anemia. Sebuah studi menemukan bahwa kepatuhan pada suplemen zat besi di antara wanita hamil berhubungan positif dengan konsentrasi Hemoglobin. Beberapa faktor yang terkait dengan kepatuhan yang tinggi dalam mengkonsumsi zat besi adalah karena tingkat pengetahuan 
dan sikap yang baik, serta faktor kepatuhan yang rendah dalam mengkonsumsi zat besi karena tidak menyukai rasa pil suplemen zat besi, dan mempunyai sifat pelupa. Terdapat banyak studi penelitian bahwa kepatuhan pada suplemen zat besi di antara wanita hamil berhubungan positif dengan kejadian anemia (Rukmaini, et.al, 2018).

Pengetahuan dan sikap ibu yang baik tentang anemia dan tablet tambah darah $(\mathrm{Fe})$ serta kepatuhan dalam mengkonsumsi tablet $\mathrm{Fe}$ dapat menjadi factor yang akan berhubungan dengan kadar haemoglobin (HB) ibu dan kepatuhan ibu dalam mengkonsumsi tablet $\mathrm{Fe}$ akan mempengaruhi kondisi ibu saat persalinan nantinya (Nils Milman, 2012).

Anemia postpartum adalah suatu keadaan dimana seorang ibu sudah melahirkan sampai dengan kira-kira 5 minggu dalam kondisi pucat, lemah, dan kurang bertenaga. Anemia sedang adalah dimana kadar hemoglobin berkisar antara 6-8 $\mathrm{gr} / \mathrm{dL}$ (Proverawati, 2011). Hal ini diperburuk dengan kehilangan darah saat melahirkan dan pada masa nifas. Anemia adalah suatu keadaan dimana seorang ibu sehabis melahirkan sampai dengan kira-kira 5 minggu dalam kondisi pucat, lemah dan kurang bertenaga. Pada masa ini masalah dan komplikasi dapat saja terjadi pada ibu pasca melahirkan seperti haemoragic post partum, atonia uteri, dan lain-lain (Prawirohardjo, 2012).

Anemia merupakan masalah medik yang sering dijumpai di klinik seluruh dunia, disamping sebagai masalah kesehatan utama masyarakat, terutama dinegara berkembang. Kelainan ini merupakan penyebab debilitas kronik (cronic debility) yang mempunyai dampak besar terhadap kesejahteraan social dan ekonomi, serta kesehatan fisik. Oleh karena frekuensinya yang demikian sering terjadi anemia, terutama anemia ringan sering kali tidak mendapat perhatian dan dilewati oleh para dokter maupun bidan di praktek klinik (Sudoyo, 2010).

Profilaksis anemia pasca persalinan harus dimulai pada awal kehamilan untuk memastikan status zat besi yang baik sebelum melahirkan. Cara yang paling andal untuk menangani masalah ini adalah memberi suplemen zat besi oral profilaksis 30-50 mg setiap hari dari awal kehamilan dan melakukan tindakan pencegahan kebidanan pada kehamilan yang berisiko mengalami komplikasi. Dalam pengobatan IDA (Iron Defeciency Anemia) pasca melahirkan ringan, yang menjadi pilihan pertama harus zat besi besi oral 100 sampai $200 \mathrm{mg}$ setiap hari, dan penting untuk menganalisis kadar hemoglobin setelah kira-kira 2 minggu untuk memeriksa apakah pengobatan berhasil (Nils Milman, 2012).

Pengetahuan merupakan aspek penting dalam prilaku seseorang. Pengetahuan dapat membentuk keyakinan tertentu, sehingga seseorang berperilaku sesuai dengan keyakinan tersebut (Notoatmodjo, 2014). Pengetahuan akan pentingnya tablet $\mathrm{Fe}$ akan mempengaruhi kesadaran seseorang dalam mengkonsumsi tablet $\mathrm{Fe}$, serta hal ini akan ditunjang dengan Sikap yang baik tentang tablet $\mathrm{Fe}$ akan mendukung terlaksananya kepatuhan dalam mengkonsusmsi Fe setiap hari sebagai upaya sadar dari diri seseorang dalam menjaga kehamilannya (Pujiastuti, 2017). Kurangnya pengetahuan ibu tentang permasalahan/komplikasi yang dapat timbul dalam kehamilan, pemeriksaan kehamilan yang tidak rutin, penanganan persalinan yang tidak baik, akan mempengaruhi kualitas kesehatan ibu dan janin. Ketika ibu memiliki banyak informasi kehamilan, sekalipun yang bersangkutan baru pertama kali hamil, ia akan lebih tenang karena ia paham hal tersebut adalah sebuah fase normal dan alamiah dari sebuah proses kehamilan. Berbagai sumber informasi dapat diperoleh dari buku, majalah, surat kabar atau sumber dari internet yang beragam jenisnya. Web / situs kesehatan dari instansi kesehatan sangat mendukung bagi ibu hamil untuk menambah pengetahuannya dalam menjalani kehamilan yang sehat. Kemudahan mendapatkan informasi inilah yang sekiranya membantu ibu hamil untuk meng-update referensi kehamilannya. Sharing dengan orang tua ataupun kerabat yang telah mempunyai pengalaman juga menjadi alternatif untuk 
memperkaya informasi kehamilan (Pujiastuti, 2017).

Pada penelitian ini kepatuhan responden dalam mengkonsumsi tablet $\mathrm{Fe}$ dinilai berdasarkan kuesioner dan jumlah sisa tablet Fe yang diberikan pada responden. Peneliti memberikan 30 tablet $\mathrm{Fe}$ pada 20 orang responden ibu hamil $\geq 32$ minggu yang dianjurkan untuk dikonsumsi $1 \mathrm{x}$ sehari pada malam hari. Peneliti melakukan follow up (untuk mengingatkan $2 \mathrm{x}$ seminggu melalui SMS (short massage services). Beberapa kendala yang disampaikan responden terkait dengan kepatuhannya mengkonsumsi tablet $\mathrm{Fe}$, diantaranya; sifat lupa, malas makan obat, sulit makan obat karena harus disertai pisang. Dari 13 responden yang patuh mengkonsumsi tablet $\mathrm{Fe}$ masih terdapat 4 responden yang mengalami anemia ringan dan 9 responden tidak anemia. Hal ini dapat saja terjadi meskipun ibu termasuk rajin dan rutin mengkonsumsi tablet $\mathrm{Fe}$ karena ada faktor lain yang mempengaruhi terjadinya anemia pada seseorang seperti; asupan nutrisi yang kurang bergizi, penyakit yang menyertai kehamilan, dan lain-lain. Sementara dari 7 responden yang tidak patuh mengkonsumsi tablet $\mathrm{Fe}$ terdapat 6 orang diantaranya mengalami anemia.

Untuk mendapatkan data kadar Haemoglobin ibu dilakukan pada saat 2 jam pasca persalinan dengan cara bedside one serial timing. Disamping itu saat penelitian ini juga mengevaluasi output persalinan responden, seperti; jumlah darah, Apgar Score (AS) bayi yang lahir, tingkat kelelahan saat bersalin. Hasil penilaian jumlah darah masih dalam batas normal terbukti semua responden pulang dalam kondisi sehat dari klinik bersalin, terdapat hanya 1 bayi lahir dengan AS 7/8 dari ibu dengan kadar HB 7 $\mathrm{gr} / \mathrm{dL}$ serta terdapat tindakan invasive pemasangan infuse terhadap 7 responden saat persalinan yang 5 diantaranya memang mengalami anemia dengan indikasi pemasangan; 3 responden kelelahan dan 4 responden mengalami his tidak kuat (inersia uteri). Kondisi ini diduga dipengaruhi juga oleh faktor lainnya seperti paritas, umur ibu saat melahirkan.
Pada aspek intervensi pemberian infuse, diperoleh data dari 20 responden terdapat 7 responden yang diberikan cairan infuse sebagai bantuan energy dan cairan tubuh bagi responden saat persalinan, dengan 3 indikasi kelelahan dan 4 indikasi his tidak adekuat (inersia uteri). Hal ini menunjukkan bahwa saat persalinan otot uterus mengalami kelelahan dan kebutuhan energy berkurang akibat pasokan oksigen yang kurang sehingga kekuatan otot untuk berkontraksi menjadi lemah saat persalinan. Pemberian infuse pada responden bertujuan untuk menambah tenaga ibu dan mempercepat persalinan ibu (accelerasi persalinan).

Penanganan kelelahan biasanya dengan memberikan minuman air gula dan terapi cairan infus untuk mengembalikan elektrolit tubuh saat (Linda J. 1999, Joan Elizabeth, 1999) dan pemberian air kelapa sebagai penanganan kelelahan (Dwi, 2014). Hasil penelitian Wahyuni, dkk, 2017 dalam rangka membantu mengatasi kelelahan ibu saat persalinan dapat dilakukan dengan pemberian jus semangka $500 \mathrm{~mL}$.

Pemberian cairan dan nutrisi saat persalinan berlangsung akan memberikan lebih banyak energi dan mencegah dehidrasi yang berakibat memperlambat kontraksi atau membuat kontraksi tidak teratur. Wanita bersalin membutuhkan $\pm 50-100 \mathrm{kKal}$ energi setiap jam yang mesti terpenuhi saat persalinan sehingga mencegah terjadinya kelelahan otot dan kelaparan. Jika cadangan glukosa tidak tersedia cadangan lemak akan digunakan dan akan mengakibatkan ketosis pada akhirnya terjadi ketonuria, yang menyebabkan kerja miometrium berkurang (Rukiah, 2009).

Kelelahan yang dialami ibu saat persalinan diakibatkan karena nyeri kontraksi rahim yang dirasakan, sehingga terjadi dehidrasi dan peningkatan rasa haus. Saat kontraksi, proses metabolism energi sangat tinggi dan sistem termoregulator tubuh meningkatkan suhuh tubuh dan peningkatan produksi kelenjar keringat, berakhir dengan kurang cairan pada tubuh dan kompensasi yang dirasakan tubuh adalah rasa haus. 
Untuk itu perlunya upaya mengembalikan kadar cairan tubuh saat kontraksi otot intensitas tinggi (Wahyuni, dkk, 2017).

Disamping itu kurangmya asupan nutrisi dan zat besi selama kehamilan akan mempengaruhi kekuatan kontraksi otot rahim lemah saat persalinan, sehingga pembukaan cervik menjadi lama dan proses persalinan dapat berjalan lambat. Pentingnya kesadaran ibu dalam mengkonsumsi tablet Fe saat hamil dapat membantu memberikan suplai oksigen dan nutrisi yang cukup ke otot rahim selama kehamilan dan sangat membantu kekuatan otot rahim berkontraksi saat masa melahirkan.

Tablet zat besi $(\mathrm{Fe})$ yang dikonsumsi selama kehamilan menjadi bantuan cadangan energy selama kehamilan agar uterus dapat berkontraksi dengan baik saat persalinan. Tablet zat besi akan menambah jumlah eritrosit dalam darah sehingga kemampuan nya mengangkut oksigen juga meningkat. Dampak kekurangan zat besi adalah partus lama, his irregular (inersia uteri), Berat bayi lahir rendah / prematuritas, atonia uteri, dan lain-lain (Prawirohardjo, 2012).

Penyerapan zat besi oleh enterosit ini terjadi terutama di bagian duodenum dan jejunum atas. Ini kemudian ditransfer melintasi mukosa duodenum ke dalam darah, di mana ia diangkut dengan transferrin ke sel-sel atau sumsum tulang untuk erythropoiesis (memproduksi sel darah merah / eritrosit). Ada mekanisme umpan balik yang meningkatkan penyerapan zat besi pada orang yang kekurangan zat besi. Sebaliknya, orang yang kelebihan zat besi meredam penyerapan zat besi melalui hepcidin. Penyerapan zat besi dikendalikan oleh ferroportin yang memungkinkan atau tidak membiarkan zat besi dari sel mukosa masuk ke dalam plasma, Konsentrasi feritin bersama dengan hemosiderin mencerminkan simpanan zat besi tubuh. zat besi disimpan dalam bentuk yang tidak larut dan terdapat terutama di hati, limpa, dan sumsum tulang. Mayoritas zat besi terikat dengan pengikat zat besi yaitu protein, yang salah satunya pada protein sel darah merah (eritrosit) (Nazanin, et.al 2014).

\section{Kesimpulan}

Kepatuhan ibu hamil dalam mengkonsumsi tablet $\mathrm{Fe}$ selama kehamilan dapat mempengaruhi kadar haemoglobin atau kejadian anemia pada saat post partum, untuk itu disarankan kepada bidan sebagai tenaga kesehatan untuk dapat meningkatkan penyuluhan dan edukasi tentang pentingnya kepatuhan ibu dalam mengkonsumsi tablet tambah darah saat ANC sehingga dapat meminimalkan resiko kejadian komplikasi dan anemia pada saat persalinan.

\section{Referensi}

Azwar, S. 2009. Sikap Manusia, Teori dan Pengukurannya. Jakarta: Pustaka Pelajar

Dwi, Noer Aini, 2014. Efektivitas pemberian air kelapa muda terhadap lama persalinan kala II pada ibu bersalin di BPM Pungging Mojokerto. Akses 20 Maret 2017

Elizabeth J. Corwin ${ }^{2}$, Laura E. MurrayKolb*, and John L. Beard*2003. Low Hemoglobin Level Is a Risk Factor for Postpartum Depression. The American Society for Nutritional Sciences

Linda J. Mayberry, RN, PhD. Susan Gennaro, RN, DSN. Laura Strange, RN, MS. Marie Williams, RN, MS. Anindya De, $\mathrm{PhD}$. 1999. Maternal Fatigue: Implications of Second Stage Labor Nursing Care. Journal of Obstetric, Gynecologic \& Neonatal Nursing Volume 28, Issue 2, March 1999, Pages 175181

Ludwig, $\quad H . \quad$ \&Strasser, $\quad K$. (2001).Symptomatology of anemia.Semin.Oncol.28(suppl. 8):7-14

Nazanin Abbaspour, Richard Hurrell,1 and Roya Kelishadi2 , 2014. Review on iron and its importance for human health, J Res Med Sci. 2014 Feb; 19(2): 164-174. PMCID: PMC3999603. PMID: 
24778671.

https://www.ncbi.nlm.nih.gov/pm c/articles/PMC3999603/

Nils Milman, 2011. Review article; Postpartum anemia I: definition, prevalence, causes, and consequences..Annals of Hematology.November 2011, 90:1247

Notoatmodjo, 2010. Ilmu prilaku kesehatan : Jakarta ; Rineka Cipta

Notoatmodjo, S. 2003. Ilmu Kesehatan Masyarakat Prinsip-prinsip Dasar. Jakarta: Rineka Cipta

Nurul Hikmah, Dian Puspita Yani. Gambaran Hemorogic Post Partum pada Ibu Bersalin dengan Kejadian Anemia di Ruang Ponek RSUD Kabupaten Jombang, Jurnal EDU Health, Vol. 5 No. 2, September 2015

Prawirohardjo. 2012. Ilmu Kebidanan. Jakarta: Yayasan Bina Pustaka

Proverawati, Atikah.2011. Anemia dalamKehamilan.Yogyakarta : Nuha Medika

Pujiastuti, 2017. Konsep Kehamilan Sehat: Upaya Mencetak Generasi Cerdas Pujiastuti, Ana 2017 http://eprints.uad.ac.id/8172/1/kon sep\%20kehamilan\%20sehat $\% 2 \mathrm{C}$ \%20upaya\%20mencetak\%20gene rasi\%20cerdas.pdf

Rukiah, Ai Yeyeh. 2009. Asuhan Kebidanan I (Kehamilan). Jakarta : Trans info media

Rukmaini, N.I. Lipoeto, Masrul, N. Effendi, 2018. Effect of Mobile Control Application on the Compliance of Ferrum Tablets Consumption Among Pregnant Women. Journal of Medical Sciences. ISSN 1682-4474. DOI: 10.3923/jms.2018.63.68. https://scialert.net/fulltext/?doi=j ms.2018.63.68

Sudoyo Aru W dkk.2010.Ilmu Penyakit dalam. Jakarta : Internal publishing
Sugiyono. 2012. Metode Penelitian Pendidikan (Pen-dekatan Kuantitatif, Kualitatif, dan R\&D). Bandung: Alfabeta

Suwandi.(2010). Survey AKI dan AKB di Indonesia. Tersedia dalam: Survey Demografi dan Kesehatan Indonesia tahun 2012. http://j3ffunk.blogspot.com/2011/ 05/survey-aki-dan-akb-di-

indonesia.html. [diakses tanggal 28 April 2019]

Wahyuni Islah, Binarwan Halim, Rusdiana, Muhammad Rusda, Muhammad Ichwan 2017. Managemen Kelelahan Saat Persalinan Menggunakan Jus Semangka, jurnal iptek terapan, JURNAL IPTEKS TERAPAN Research of Applied Science and Education V12.i 1 (19-31) Kopertis Wilayah X 20 ISSN: 1979-9292. E-ISSN:2460-5611

Wahyuni S. (2015). Anemia dalam Kehamilan. Terdapat dalam https://sriwahyunimcb13.wordpre ss.com/2015/05/27/anemia-dalam kehamilan/.Diakses tanggal 05 Mei 2019. 